\title{
Dual Process Difference in Families Regarding Home Buying Decision
}

\author{
${ }^{1}$ Anastasia, Njo; ${ }^{2}$ Narsa, I Made \\ ${ }^{1}$ Finance Program, Petra Christian University, Surabaya, Indonesia \\ ${ }^{2}$ Accounting Department, Universitas Airlangga, Surabaya, Indonesia \\ anas@petra.ac.id
}

\begin{abstract}
The system of thought between rational systems and experience systems is inherent in each individual and produces different decisions. Thinking using logic tends to be used by almost every individual, but cognitive limitations make the individual simplify complex thinking to make practical decisions. This study aims to examine more in dual process on decision home buyers according to dual motives based on demographics and life cycle. Data collection was done by distributing questionnaires to selective home buyers of 235 buyers. Survey instruments include demographic and family life cycle variables. The dual process measurements using Rational-Experiential Inventory (REI-40) are designed to test individual preferences for two decision making, such as cognitive styles (rationality) and intuition (experience) using Likert scales. The results show that dual process cannot be distinguished based on dual motives. However, demographic variables such as gender, age, education, and family life cycle showed the difference in the dual process.
\end{abstract}

Keywords: Dual Process, Dual Motives, Demography, Family Life Cycle

\section{Introduction}

A rational person is assumed to be a person who obeys the rules, but rationality also has its limits. One cannot do it perfectly due to cognitive limitations, logical fallacies, miscast implications, and limited time allocation (Simon, 1973). Basically, there are two perspectives on how a person reacts to something. The first perspective has been supported by experiments that proved there are two contrast cognitive systems; rational analysis (called executive-analytic) and an experimental-intuitive system called heuristic (Epstein, Pacini, Denes-Raj, \& Heier, 1996; Stanovich \& West, 1998; De Neys, 2006). Both systems support a person to use their reasoning with dual-process to help analyze alternatives and decide on a better decision. On the contrary, the second perspective states that humans draw conclusions based on logical deductions, cognitive capabilities, knowledge, and limited time so a simple psychological mechanism is called pragmatic heuristic (Gigerenzer \& Goldstein, 1996). Both groups, rational cognitive versus experience and the pragmatic heuristic is still in debate, which is the consequence of automatic intuitive response or the consequence of a certain cognitive of a person. Individual differences such as causal reasoning, cognitive capability, cognitive reflection, numerical measure, and rational and intuitive thinking styles have a great impact on decision or bias. Shiloh, Salton, \& Sharabi (2002) found that normative response correlates positively with rational thinking style, and negatively with experimental intuitive thinking style.

The rational style combines the use of intentional rule-based criteria, analytical, and critical evaluation of evidence so the process of decision making is structured. Conversely, experimental style is thought to be automatic, quick, recognizable, and intuitive, because it is affected by the condition, private disposition, and emotional passion. Furthermore, preference in decision-making style and thinking which is done in this study sees the possibility of diversity among a certain population, namely homebuyers and property investors. Young families as first-time homebuyers have a consumption motive, and therefore tend to use rational thinking process. Their experience as buyers is low, so their decision-making is affected by their current information and cognitive knowledge. Meanwhile, the investors, coming from a financially more capable family, have done a lot of transactions and therefore are a lot more experienced compared to first-time buyers. Decision-making tends to involve experience and intuition (Njo, Made-Narsa, \& Irwanto, 2017). Gender stereotype also shows that women tend to get involved in experience-based processes, while men in rational processes (Epstein, 2003). Pacini \& Epstein (1999) have done a revision on analytical and intuitive thought testing, which is called Rational-Experiential Inventory (REI), using 40 items to increase instrument's reliability. 
This study uses said instrument towards buyers and property investors to measure rational cognitive and intuitive styles (dual process) while completing transactions of house purchasing in Indonesia. This study is an extension of Njo, Made-Narsa, \& Irwanto (2017) study involving dual motives and dual process. The aim of this study is to empirically test the differences dual process in buyers and investors regarding decisionmaking in housing purchase. The differences are viewed from demography and stage of family life perspective. Dual process in each family stage becomes crucial to be understood clearly so as to plan family financially in order to avoid making a biased decision. A family that is able to plan family financial wisely is expected to achieve their life goals. Furthermore, understanding the dual process which is rational system and experience system based on demography and stage of family life in relation to the motive of purchase can provide an insight about family financial planning, marketing strategy, and property development plan. This insight can be used to minimalize losses suffered by every party involved in the real estate market.

\section{Literature Review}

Dual Process: Perspective from Cognitive Experiential Self Theory shows result from two different processing system, rational and experience. Both systems operate synchronously and produce a compromise, but at times contradict themselves, resulting in a conflict between heart and head (Epstein, 1994). Development from dual process occurs in numerous fields including decision-making (Kahneman \& Frederick, 2002) Quick, autonomous and easy, against slow, sequential and controlled. A number of theories have tried to map dual process on two cognitive systems with different names, which is experience-rational (Epstein, 1994), heuristic-analytical (Evans, 1989), and system 1 and system 2 (Stanovich, 1999). Experience system (system 1) and rational system (system 2) operates in parallel and interactively (Epstein, 2003) as grouped in Table 1. Epstein (2003) states that the experience system affects the rational system. The experience system is quick, operates automatically and subconsciously. When an individual thinks rationally, bias may occur through the experience process. Bias affect a rational mind when experience system operates as the scheme an individual acquire from past experience. In some cases, however, a bias which is based on experience and upcoming rationalization is very maladaptive. Experience system can affect a rational system both positively or negatively. As an associative system, experience system can become a source of creativity through ideas which are not present in the rational system. The experience system is a learning system which can be used as a source of information to penetrate into a rational system. The most important thing however, is that experience system can be used as a fuel for passion in a rational system, so the intellectual pursuit can be done with caution.

Table 1: Clusters of Dual-Process Theories

\begin{tabular}{llll}
\hline Type 1 process (intuitive) & \multicolumn{3}{l}{ Type 2 process (reflective) } \\
\hline $\begin{array}{l}\text { Definition: Does not require working memory } \\
\text { Requires working memory }\end{array}$ & $\begin{array}{l}\text { Definition: Autonomous Cognitive decoupling; } \\
\text { mental simulation }\end{array}$ \\
Typical correlates: Fast, High capacity, Parallel, & $\begin{array}{l}\text { Typical correlates: Slow, Capacity limited, Serial, } \\
\text { Nonconscious, Biased responses, Contextualized, }\end{array}$ & $\begin{array}{l}\text { Conscious, Normative responses, Automatic, } \\
\text { Automatic, Associative, Experience-based decision } \\
\text { making, Independent of cognitive ability }\end{array}$ & $\begin{array}{l}\text { Controlled, Rule-based, Consequential decision } \\
\text { making, Correlated with cognitive ability }\end{array}$ \\
\hline
\end{tabular}

Source: (Evans \& Stanovich, 2013)

Conversely, the rational system also affects the experience system. Rational system is slower but able to revise the experience system. An individual will contemplate on his spontaneous and impulsive thoughts, realize the inappropriate ones, and replace them with constructive ones. The rational system can also affect the experience system, where a person trains his experience system so that his initial reaction is more proper, automatically, whether intentionally or not (Epstein, 2003). Thoughts in rational system trigger emotion in experience system in an associative way, where a repeat of thoughts or initial behavior under rational control will be standard or "procedural", in which case that control will shift from rational to experience (Smith \& DeCoster, 2000). Benefit from this control shift includes the lesser need for cognitive resources in thoughts and behavior, and even allows them to happen subconsciously. However, the downside is when thoughts and behavior are in the subconscious level, it is a great deal harder to change. Pacini \& Epstein (1999) created Rational-Experiential Inventory (REI) to measure rational system and experience system. Rational system is measured using two scales, and so is the case for the experience system, which includes preferences and 
abilities. The latest version of REI uses 40 items, Rational dimension (20 items) consists of Rational Ability (RA) (10 items) which refers to the ability to think logically and analytically, and Rational Engagement (RE) (10 items) which refers to the pleasure of doing so.

Dual Process in Property Purchase: The difference between dual process, quick and intuitive, compared to slow and discussion is closely related to human reasoning and cognitive process, such as judgment and decision-making by an individual. Individual behavior is a study of physical activity, mental and emotional of an individual, group, or organization when choosing, buying, using and disposing of goods or service to fulfil their needs. Those activities include decisions made before, during, and after the procedure (Kuester, 2012). Gibler \& Nelson (2003) did a search and selection process on houses by combining behavioral and real estate theory which is called Behavioral Real Estate (BRE) (DeLisle, 1985). In the last few decades, a study on individual behavior has experienced a shift from rational factor to psychological or irrational factor (Bargh, 2002) involving decision-making process of purchases, mainly real estate products (Ajzen, 1991; Han \& Kim, 2010; Kunshan \& Yiman, 2011). Smith (1992) along with McAllister \& Mansfield (1998) states that real estate market less liquid (weak form efficient) compared to equity and obligation market. The contributing factors are massive transaction value, high transaction fee, the absence of a centralized market, low transaction frequency (especially in the homebuyers group) and delays caused by legal proceedings. Real estate market condition will affect market players, and so the decisions taken will be affected simultaneously by information and the processing of it based on experience and cognitive capabilities (Epstein, 1998).

Experience and cognitive systems can communicate with and affect each other where the balance of both systems is flexible and varied according to conditions. Experience system will improve intuitive abilities, so individual action and decision will systematically deviate from rational assumption. This condition results in a fundamental bias and persistent in decision-making that regularly produces behaviour with the inexplicable assumption (Kahneman, 2003). Houses are one of many types of housing from real estate products, where it serves two purposes which is consumption and investment (Shiller, 2007), but that statement triggered controversial debates. Conservatives do not see a house as an investment, but rather as a better and comfortable place to live. Buyers who look for houses for private use will select rationally according to their personality and lifestyle (Koklic \& Vida, 2009). While from an economic point of view, a house is an investment (Shiller, 2007) because it can provide potential revenue and profit in the future. This difference in function leads to decision-making process shifting from rational to a heuristic. Generally, consumers have a limited chance to access all available information. However, wider knowledge or insight will affect buyers' behaviour toward better comprehension and prediction in decision-making in the real estate market according to the financial commitment of buyers (Daly, Gronow, Jenkins, \& Plimmer, 2003).

House buying is one of the complex decisions to make as it requires strategy before deciding (Koklic \& Vida, 2009). This includes product profile identification, information collecting on said profile, profile evaluation based on certain criteria, and then making the most favourable decision. Decision made based on rational thinking is also called rational decision making (Green, May 2002). First homebuyers decide on the purchase rationally (Monico, 2013). Scanlon \& Whitehead (2010) also states that owners of many properties decide more rationally compared to those who only own one or two properties. But, buyers also decide heuristically by involving intuition which processes problems quicker, ignoring new information. Especially in situations with a high degree of complexity, choices, risk and uncertainty, done in high-stress and high time-pressure (Gigerenzer \& Gaissmaier, 2011; Tversky \& Kahneman, 1973; Tversky \& Kahneman, 1974). Njo, Made-Narsa, \& Irwanto, (2017) states that buyers with consumption motive tend to be rational compared to those with investment motive, which tend to be heuristic. Bias is the result of the rule of thumb, heuristic, and mental 'shortcut' that shortens information processing. A heuristic is a process of solving problems and making decisions effectively, especially in situations with a high degree of complexity, choices, risk and uncertainty (Gigerenzer \& Gaissmaier, 2011; Kahneman, Slovic, \& Tversky, 1982; Tversky \& Kahneman, 1973; Tversky \& Kahneman, 1974).

A person tends to keep their efforts heuristically, but accuracy becomes an issue (Shah \& Oppenheimer, 2008) which is caused by limited time of information gathering and efforts needed, resulting in a trade-off of loss of accuracy to speed and cognitive saving. The more complex the problem, the more alternative heuristic behavior will eliminate by limiting information gathering and evaluation. As a result, the decision made will 
be biased and inefficient, because the conclusion is drawn without effective consideration and analysis according to the parameters used (Simon, 1978). Hardin (1997) however, noted that if heuristic information processing is applied correctly, it is able to reduce search time to complete a task. Furthermore, experience dimension (20 items) consists of Experiential Ability (EA) (10 items) as an ability to recount impression and intuitive feelings, and Experiential Engagement (EE) (10 items) in regard to the feelings involved in decisionmaking based on intuition and feeling.

Hypothesis 1: Buyer with consumption motive uses Rational Ability (RA) and Rational Engagement (RE) compared to the buyer with investment motive tends to use Experiential Ability (EA) and Experiential Engagement (EE).

Dual Process Reviewed by Demography Buyer and Family Life Cycle: Demographical study in population structure and population characteristic consists of gender composition, age, education, income and job, can be used in order to understand cause and consequence of demographic phenomena, the scale or the change from time to time, and how to control population characteristic towards a certain view (Anderson, 2015). Furthermore, Family Life Cycle by Duval in 1977 is used classification on stages measured by the age of marriage (Spanier, Sauer, \& Larzelere, 1979) as shown in Table 2. The family life cycle can indicate family mobilization regarding the needs of the family, including house purchase.

Table 2: Family Life Cycle Stage Age of Marriage Scheme

\begin{tabular}{|c|c|c|c|}
\hline No. & $\begin{array}{l}\text { Family Life } \\
\text { Cycle Stage }\end{array}$ & Description & $\begin{array}{l}\text { Age of Marriage } \\
\text { (year) }\end{array}$ \\
\hline 1. & Honeymooners & Married; whether a parent or not & $0-5$ \\
\hline 2. & Full Nest & Couple with the oldest child less than 6 years old & $6-20$ \\
\hline 3. & Empty Nest & Couple with at least one child still living at home & $21-30$ \\
\hline 4. & Dissolution & $\begin{array}{l}\text { Couple living alone; spouse has passed away and currently } \\
\text { no children living with them }\end{array}$ & $31+$ \\
\hline
\end{tabular}

Source: Spanier, Sauer, \& Larzelere (1979) processed

Every family according to each of their life cycle stage will encounter dual process within themselves as their cognitive abilities develop in regard to the home buying process. The process occurring in system 2 relies on intelligence, while system 1 does not (Reber, 1993; Stanovich, 1999). Next, Colom, et al. (2004) divides individuals based on working memory capacity and intelligence measurement. Memory capacity can be used to predict performance level as long as the range of cognitive task is extensive and directly related to dual process cognitive function. The ability to think analytically contributes to performance on intelligence test as age increases. Young families will have different working memory capacity and intelligence compared to families in later stages. The difference in age in information and emotional processing along with experience processing happens as a way to compensate the decrease in cognitive resources. Thinking logic and belief significantly affect decisions made, but the two are personally contradicting in an individual. Ability to resolve a conflict consistent with cognitive abilities (Newstead et al., 2004), decreases later along with age (Gilinsky \& Judd, 1994) and creates a disastrous result when responded swiftly (Evans \& Curtis-Holmes, 2005).

Pacini \& Epstein (1999) proved there are significant gender-based differences on every REI scales except Rational Engagement (RE). Men scored Rational Ability (RA) slightly higher compared to women, while women scored Experiential Engagement (EE) slightly higher compared to men. The difference in an age when considering decisions also occurs as a result of age in effective process beside the change caused by the discussion process. The first observation based on age shows that grown adults tend to gather lesser information and use simpler strategy compared to young adults, their choices are not varied. Second, grown adults experience a decline of cognitive resources, so they are more selective on using it and will not bother to put more efforts to reach a better decision. Affective and emotional information tend to affect decision and judgment more on grown adults compared to young adults, caused by the decline of ability to discuss or by the change of motivation when they feel the end of their life is approaching. Individuals will process information qualitatively as they grow in age, along with experience. Hence, the aging process affects grown adults advantageously in decision-making compared to young adults in the certain situation, although it 
worsens in unforeseen situations. Understanding the changes an individual goes through along with age can help identify means to improve decision-making such as home buying (Peters et al., 2008).

Hypothesis 2: Rational system and experience system in the dual process which occurs in a homebuyer shows significant differences based on buyer's demographical background (gender, age, education, income, and job) and family life cycle.

Hypothesis 3: Homebuyers in an older family group tend to use experience system compared to those in the younger family group who use a rational system.

\section{Methodology}

This quantitative study is explanatory, meaning it analyzes the correlation between variables family life cycle and dual process. This study's population is individual who lives in major cities in Indonesia and is in different family life cycle stage, was involved in a home buying transaction regardless of the region, at least within the year. This period of time is chosen consistent with (Nickerson, 1968)'s study which states Long Term Memory (LTM) can remain after one year although degrades from $92 \%$ to $63 \%$. Sample withdrawal technique uses a convenience sampling method where the respondent's sample is chosen appropriately to its availability in property exhibition halls, property broker offices, and developer offices. Data extraction is done through questionnaires spread to two hundred fifty (250) respondents, but after selection it is reduced to two hundred thirty-five (235) respondents. Respondents are asked to complete paper and electronic survey instruments which consist of demographical questions (gender, age, education, income, and occupation), family life cycle (marriage age) and Rational-Experiential Inventory (REI-40) containing 40 questions designed to test individual preferences to 2 decision-making styles: cognition (rationality) and intuition (experience), using Likert scale 1-5 points, definitely wrong (1) to correct (5). Every question demands each respondent to reflect on his own ability or feeling regarding rational or experiential decision-making activity as such: Rational ability refers to the ability to think logically and analytically (which is "I have a logical mind" Rational involvement refers to the dependence and pleasure felt when using logical and analytical thinking (which is "I enjoy intellectual challenges") Experiential ability refers to the ability felt regarding intuitive impressions and feelings. which is trust my feeling") Experiential involvement refers to the dependence and pleasure felt when using feelings and intuitions (which is tend to use my heart to lead my actions").

Table 3: Description of Variable

\begin{tabular}{|c|c|c|c|c|}
\hline No & Variable & Code & Measurements & Questionnaire number \\
\hline \multirow[t]{4}{*}{1} & Dual Process & RA & Rational -Likert scale & $(1+4+8+13+14+17+25+27+30+39) / 10$ \\
\hline & & RE & & $\begin{array}{l}(2+6+10+16+20+26+28+32+33+ \\
40) / 10\end{array}$ \\
\hline & & EA & $\begin{array}{l}\text { Experiential -Likert } \\
\text { scale }\end{array}$ & $\begin{array}{l}(3+5+18+19+21+34+35+36+37+ \\
38) / 10\end{array}$ \\
\hline & & $\mathrm{EE}$ & & $\begin{array}{l}(7+9+11+12+15+22+23+24+29+ \\
31) / 10\end{array}$ \\
\hline 2 & Dual Motives & DM & Dummy & $\begin{array}{l}1=\text { consumption } \\
0=\text { investment }\end{array}$ \\
\hline 3 & Sex & Sex & Dummy & $\begin{array}{l}1=\text { man } \\
0=\text { woman }\end{array}$ \\
\hline 4 & Age & Age & nominal & $\begin{array}{l}1=<20 \text { years } \\
2=21-30 \text { years } \\
3=31-40 \text { years } \\
4=41-50 \text { years } \\
5=>51 \text { years }\end{array}$ \\
\hline 5 & Education & Educ & nominal & $\begin{array}{l}1=<\text { High school } \\
2=\text { Undergraduate } \\
3=\text { Master's degree } \\
4=\text { Doctoral degree } \\
5=\text { Others }\end{array}$ \\
\hline
\end{tabular}




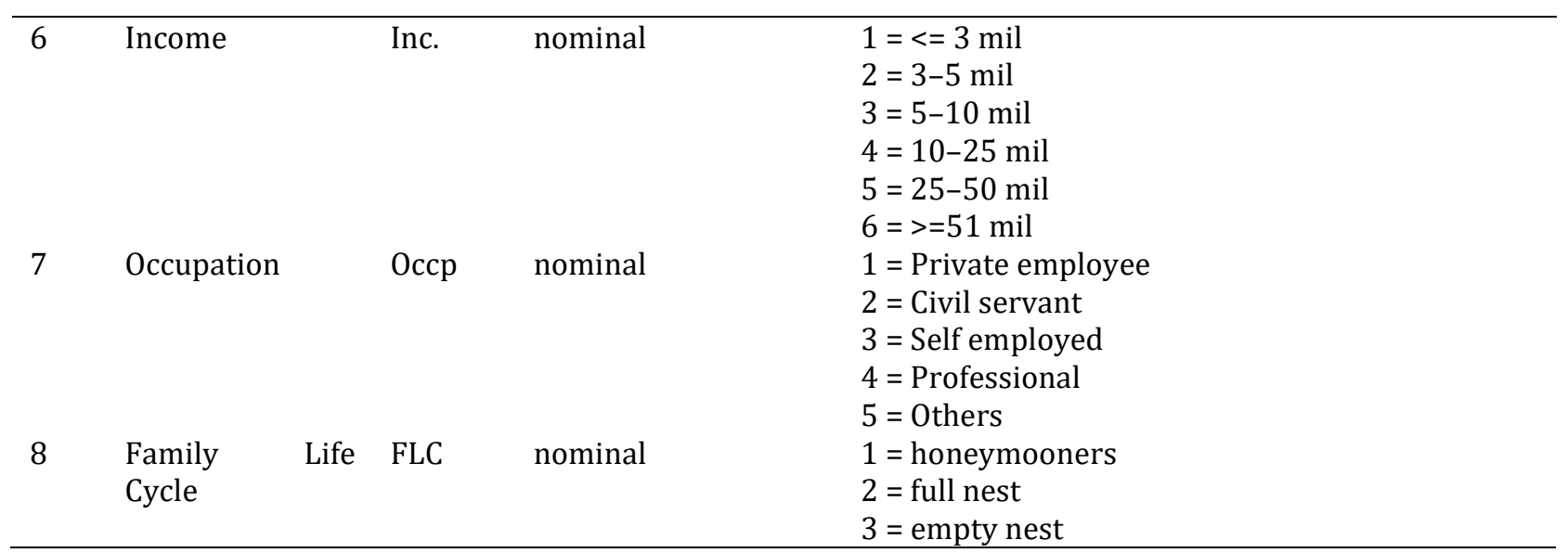

Data processing begins with reverse in REI-40 for numbers: 4, 6, 8, 9, 10, 12, 15, 16, 22, 25, 27, 29, 32, 33, 35, $36,37,38$, and 39. The rational score is achieved by adding responses from Rational Ability (RA) and Rational Engagement (RE), while experience score is achieved by adding Experiential Ability (EA) and Experiential Engagement (EE). Followed by a validation test, reliability test, and normality test. Quantitative data analysis uses SPSS ver.21 (IBM Corp). Continued data will be presented in the mean. To follow up on the significant difference between groups, ANOVA and corrected coupled comparison following the Games-Howell procedure is used (unequal sample size). Statistic hypothesis testing uses alpha $\alpha=0.05$.

\section{Results and Discussion}

Dual process study using Rational-Experiential Inventory (REI-40) as information processing measuring instrument in individual has been applied to various population such as scholars (Epstein et al., 1996), paramedic (Jensen, et al., 2013), prospective jury (Gunnell \& Ceci, 2010), cardiologist (Sladek et al., 2008), and emergency room doctors (Calder, et al., 2012). Those psychometric instruments have passed validity and reliability test with Cronbach's Alpha score 0.74-0.91. Therefore, REI-40 is used in this study, and have been translated into Indonesian and spread to homebuyers in Indonesia. Next, Content Validity Ratio (CVR) test is done to each instrument with Aiken's value above 0.35 , so the questionnaire's instruments can be used in the following studies. After CVR test, validity test is done as required in significant Pearson Correlation on level 0.05 and reliability test shows Cronbach's Alpha between $0.601-0.863>0.6$, meaning instruments used in decision-making model are valid and reliable. Respondent's description is reviewed from gender, age, education, occupation, and family life cycle (marriage age), and then categorized based on homebuying motive as per Table 4. There are 132 respondents with consumption motive, and 103 with investment motive.

Table 4: Homebuyer Profile and Correlation

\begin{tabular}{llllll}
\hline Profile & $\begin{array}{l}\text { Frekuensi } \\
\text { Consumption }\end{array}$ & Investment & $\begin{array}{l}\text { Percentage } \\
\text { Consumption }\end{array}$ & $\begin{array}{l}\text { Pearson's } \\
\text { Investment }\end{array}$ & $\begin{array}{l}\text { Correlation } \\
\text { Sig. }\end{array}$ \\
\hline $\begin{array}{l}\text { Gender: } \\
\text { Male }\end{array}$ & 74 & 63 & 54.0 & 46.0 & \\
Female & 58 & 40 & 59.2 & 40.8 & .433 \\
Age & & & & & \\
<20 years & 2 & 2 & 50.0 & 50.0 & \\
21-30 years & 53 & 19 & 73.6 & 26.4 & \\
31-40 years & 45 & 33 & 57.7 & 42.3 & \\
41-50 years & 21 & 32 & 39.6 & 60.4 & .000 \\
$>$ 51 years & 11 & 17 & 39.3 & 60.7 & \\
Education: & & & & & \\
SHigh school & 25 & 15 & 62.5 & 37.5 & \\
Undergraduate & 89 & 66 & 57.4 & 42.6 & \\
\hline
\end{tabular}




\begin{tabular}{|c|c|c|c|c|c|}
\hline \multicolumn{6}{|c|}{$\begin{array}{l}\text { Journal of Economics and Behavioral Studies (ISSN: 2220-6140) } \\
\text { Vol. 10, No. 6, pp. 272-284, December } 2018\end{array}$} \\
\hline \multirow[b]{2}{*}{ Profile } & \multicolumn{2}{|l|}{ Frekuensi } & \multicolumn{2}{|l|}{ Percentage } & \multirow{2}{*}{$\begin{array}{l}\text { Pearson's } \\
\text { Correlation } \\
\text { Sig. }\end{array}$} \\
\hline & Consumption & Investment & Consumption & Investment & \\
\hline Master's degree & 11 & 15 & 42.3 & 57.7 & \\
\hline Doctoral degree & 1 & 5 & 16.7 & 83.3 & \\
\hline Others & 6 & 2 & 75.0 & 25.0 & .313 \\
\hline \multicolumn{6}{|l|}{ Income: } \\
\hline$\leq$ Rp.3 mil & 6 & 3 & 66.7 & 33.3 & \\
\hline Rp.3 mil - Rp.5 mil & 30 & 11 & 73.2 & 26.8 & \\
\hline Rp.5 mil - Rp.10 mil & 29 & 15 & 65.9 & 34.1 & \\
\hline Rp.10 mil - Rp.25 mil & 34 & 29 & 54.0 & 46.0 & \\
\hline Rp.25 mil - Rp.50 mil & 17 & 26 & 39.5 & 60.5 & \\
\hline$\geq$ Rp.50 mil & 16 & 19 & 45.7 & 54.3 & .001 \\
\hline \multicolumn{6}{|l|}{ Occupation: } \\
\hline Private employee & 71 & 36 & 66.4 & 33.6 & \\
\hline Civil servant & 7 & 0 & 100.0 & 0.0 & \\
\hline Self employed & 42 & 46 & 47.7 & 52.3 & \\
\hline Professional & 5 & 8 & 38.5 & 61.5 & \\
\hline Other & 7 & 13 & 35.0 & 65.0 & .000 \\
\hline \multicolumn{6}{|l|}{ Family Life Cycle (FLC) } \\
\hline Honeymooners ( $0-5$ years $)$ & 85 & 38 & 69.1 & 30.9 & \\
\hline Full Nest (6-20 years) & 34 & 43 & 44.2 & 55.8 & \\
\hline Empty Nest (21-30 years) & 13 & 22 & 37.1 & 62.9 & .000 \\
\hline
\end{tabular}

There are more male buyers with consumption motive than female buyers. Respondents who need the property as living space are in the range of 40 years old and currently in the honeymoon stage, while those with investment motive are around 31-50 years old and currently in full nest stage (married for 6-20 years). The majority of respondents are undergraduates. The need of a house is also the aim for respondents with income in the Rp. 3 mil - 25 mil range, while the position of investors is held by respondents with an income above Rp. 10 mil, with private employment or self-employment as their occupation. Buyers' and investors' demographic correlates with property purchase dual motives based on age, income, occupation, and family life cycle. On the other hand, as seen in Table 5 regarding $\mathrm{H}_{1}$, it is not shown from dual process any significant differences on dual motives (accept $\mathrm{H}_{0}$ ). Furthermore, by showing rational system mean score on gender, it turns out that males are more rational compared to females, while both parties' experiential and ability engagement are equal. Getting older and higher education in an individual shows a more rational personality with the tendency to think involving rational ability (RA) and rational engagement (RE), but respondent experiential tends to increase after 51 years of age. That pattern also occurs in the family life cycle. Income and occupation groups have a similar way of thinking, although the rational thinking process slightly dominates over the experiential process. A dual process which is rational and experiential from either buyers or investors shows there is a difference based on gender, age, education, and family life cycle, and further reviewed on each of their mean value.

Table 5: Comparison Dual Process based on Homebuyers Demography

\begin{tabular}{lllllll}
\hline Demographics & $\begin{array}{l}\text { R- } \\
\text { Ability } \\
\text { Mean }\end{array}$ & $\begin{array}{l}\text { R- } \\
\text { Engagement } \\
\text { Mean }\end{array}$ & $\begin{array}{l}\text { Rational } \\
\text { Mean }\end{array}$ & $\begin{array}{l}\text { E- } \\
\text { Ability } \\
\text { Mean }\end{array}$ & $\begin{array}{l}\text { E- } \\
\text { Engagement } \\
\text { Mean }\end{array}$ & $\begin{array}{l}\text { Experiential } \\
\text { Mean }\end{array}$ \\
\hline $\begin{array}{l}\text { Dual Motives } \\
\text { Consumption (n=132) }\end{array}$ & 3.4917 & 3.2227 & 3.3572 & 3.1970 & 2.9758 & 3.0864 \\
$\begin{array}{l}\text { Investment (n=103) } \\
\text { F-value }\end{array}$ & 3.5728 & 3.3087 & 3.4408 & 3.1981 & 2.9437 & 3.0709 \\
$\begin{array}{l}\text { Gender: } \\
\text { Male (n=137) }\end{array}$ & .809 & 1.518 & 1.296 & .000 & .136 & .041 \\
$\begin{array}{l}\text { Female (n=98) } \\
\text { F-value }\end{array}$ & 3.6007 & 3.3445 & 3.4726 & 3.1839 & 2.9591 & 3.0715 \\
Age & 3.4245 & 3.1429 & 3.2837 & 3.2163 & 2.9653 & 3.0908 \\
\hline
\end{tabular}




\begin{tabular}{|c|c|c|c|c|c|c|}
\hline Demographics & $\begin{array}{l}\text { R- } \\
\text { Ability } \\
\text { Mean }\end{array}$ & $\begin{array}{l}\mathrm{R}- \\
\text { Engagement } \\
\text { Mean }\end{array}$ & $\begin{array}{l}\text { Rational } \\
\text { Mean }\end{array}$ & $\begin{array}{l}\text { E- } \\
\text { Ability } \\
\text { Mean }\end{array}$ & $\begin{array}{l}\text { E- } \\
\text { Engagement } \\
\text { Mean }\end{array}$ & $\begin{array}{l}\text { Experiential } \\
\text { Mean }\end{array}$ \\
\hline$<20$ years $(\mathrm{n}=4)$ & 3.2250 & 3.2500 & 3.2375 & 3.3000 & 2.9000 & 3.1000 \\
\hline $21-30$ years $(n=72)$ & 3.4583 & 3.1889 & 3.3236 & 3.2278 & 3.0319 & 3.1299 \\
\hline $31-40$ years $(n=78)$ & 3.5077 & 3.2513 & 3.3795 & 3.1051 & 2.8859 & 2.9955 \\
\hline $41-50$ years $(n=53)$ & 3.7509 & 3.4057 & 3.5783 & 3.1415 & 2.9358 & 3.0387 \\
\hline $51-60$ years $(n=28)$ & 3.3786 & 3.1964 & 3.2875 & 3.4679 & 3.0500 & 3.2589 \\
\hline F-value & $2.171^{*}$ & 1.433 & $2.112^{*}$ & 1.286 & $2.223^{*}$ & .610 \\
\hline \multicolumn{7}{|l|}{ Education: } \\
\hline$\leq$ High school $(n=40)$ & 3.4675 & 3.1800 & 3.3238 & 3.1925 & 2.9150 & 3.0538 \\
\hline Undergraduate $(n=155)$ & 3.5058 & 3.2310 & 3.3684 & 3.2142 & 3.0045 & 3.1094 \\
\hline Master's degree $(n=26)$ & 3.6115 & 3.4077 & 3.5096 & 3.1538 & 2.8423 & 2.9981 \\
\hline Doctoral $(n=6)$ & 4.3167 & 3.8833 & 4.1000 & 3.0833 & 2.6333 & 2.8583 \\
\hline Others $(n=8)$ & 3.3750 & 3.2875 & 3.3313 & 3.1250 & 3.0000 & 3.0625 \\
\hline F-value & $2.349^{*}$ & $3.011^{* *}$ & $3.039 * *$ & .154 & .799 & .466 \\
\hline \multicolumn{7}{|l|}{ Income: } \\
\hline$\leq \mathrm{Rp} .3$ mil $(\mathrm{n}=9)$ & 3.2444 & 3.2889 & 3.2667 & 3.2889 & 3.2444 & 3.2667 \\
\hline Rp.3-5 mil (n=41) & 3.4683 & 3.1902 & 3.3293 & 3.2098 & 3.1024 & 3.1561 \\
\hline Rp.5-10 mil $(n=44)$ & 3.4864 & 3.3295 & 3.4080 & 3.1818 & 2.9500 & 3.0659 \\
\hline Rp.10-25 mil (n=63) & 3.5937 & 3.2841 & 3.4389 & 3.1159 & 2.8556 & 2.9857 \\
\hline Rp.25-50 mil (n=43) & 3.5023 & 3.2140 & 3.3581 & 3.1698 & 2.9674 & 3.0686 \\
\hline$\geq \operatorname{Rp} .50$ mil $(n=35)$ & 3.6314 & 3.2629 & 3.4471 & 3.3600 & 2.9229 & 3.1414 \\
\hline F-value & .684 & .383 & .384 & .854 & 1.055 & .743 \\
\hline \multicolumn{7}{|l|}{ Occupation: } \\
\hline $\begin{array}{l}\text { Private } \\
(\mathrm{n}=107)\end{array}$ & 3.5477 & 3.2832 & 3.4154 & 3.1944 & 2.9944 & 3.0944 \\
\hline Civil servant $(n=7)$ & 3.4571 & 3.1286 & 3.2929 & 3.0429 & 2.8286 & 2.9357 \\
\hline Self employed (n=88) & 3.5057 & 3.2193 & 3.3625 & 3.2432 & 2.9955 & 3.1193 \\
\hline Professional (n=13) & 3.5154 & 3.3077 & 3.4115 & 3.1154 & 2.9077 & 3.0115 \\
\hline Other $(n=20)$ & 3.5450 & 3.3350 & 3.4400 & 3.1200 & 2.7200 & 2.9200 \\
\hline F_value & .067 & .408 & .201 & .404 & .882 & .647 \\
\hline \multicolumn{7}{|l|}{ Family Life Cycle (FLC) } \\
\hline Honeymooners $(n=123)$ & 3.4715 & 3.2089 & 3.3402 & 3.2179 & 3.0195 & 3.1187 \\
\hline Full Nest $(n=77)$ & 3.6130 & 3.3299 & 3.4714 & 3.0792 & 2.8260 & 2.9526 \\
\hline Empty Nest (n=35) & 3.5343 & 3.2886 & 3.4114 & 3.3857 & 3.0571 & 3.2214 \\
\hline F-value & 1.008 & 1.285 & 1.329 & $3.528^{* *}$ & $2.490^{*}$ & $3.229 * *$ \\
\hline
\end{tabular}

Note: RA=Rational Ability; RE=Rational Engagement; EA=Experiential Ability; EE=Experiential Engagement; ANOVA F-value sig. ${ }^{* *} \mathrm{p}<0.05^{*} \mathrm{p}<0.1$

Table 6 shows Levene Test results with p-value $>0.05$, so the data is deemed homogeneous along with dual process ANOVA test result by gender (137 male; 98 female). Post Hoc test on RA among male ( $M=3.6007)$ shows a difference compared to female $(\mathrm{M}=3.4245)$ with $\mathrm{p}$-value .052 , as well as in RE in male $(\mathrm{M}=3.3445)$ and female $(\mathrm{M}=3.1429)$ with p-value .004. Post Hoc test on EA and EE does not show any difference based on gender. $\mathrm{H}_{2}$ proves that dual process on a rational system shows a difference between male and female, but none on the experiential system.

Table 6: ANOVA Findings for Dual Process vs Sex

\begin{tabular}{lllllllll}
\hline & & Sum & of & & Mean & & & Levene \\
& & Squares & Df & Square & F & Sig. & Statistic & Sig. \\
\hline RA & Between groups & 1.775 & 1 & 1.775 & 3.815 & $.052^{*}$ & .210 & .647 \\
& Within groups & 108.391 & 233 & .465 & & & & \\
& Total & 110.166 & 234 & & & & & \\
RE & Between groups & 2.324 & 1 & 2.324 & 8.483 & $.004^{* *}$ & .145 & .704 \\
& Within groups & 63.818 & 233 & .274 & & & & \\
\hline
\end{tabular}




\begin{tabular}{|c|c|c|c|c|c|c|c|c|}
\hline & Total & 66.142 & 234 & & & & & \\
\hline \multirow{3}{*}{ EA } & Between groups & .060 & 1 & .060 & .174 & .677 & 1.831 & .177 \\
\hline & Within groups & 80.179 & 233 & .344 & & & & \\
\hline & Total & 80.238 & 234 & & & & & \\
\hline \multirow[t]{3}{*}{ EE } & Between groups & .002 & 1 & .002 & .005 & .944 & .115 & .734 \\
\hline & Within groups & $102 . .213$ & 233 & .439 & & & & \\
\hline & Total & 102.215 & 234 & & & & & \\
\hline
\end{tabular}

sig.* $\mathrm{p}<0.05 * \mathrm{p}<0.1$

Table 7 shows the Levene Test result with p-value $>0.05$, hence data is deemed homogeneous. So, apart from RA, difference test among groups refers to Welch test. Dual process ANOVA test result by age describes Post Hoc test on RA in age group of 21-30 years old $(n=72)(M=3.4583)$ shows a difference compared to group of 41-50 years old $(n=53)(M=3.7509)$ with p-value .084 , as well as EA in group of 31-40 years old $(n=78)$ $(M=3.3445)$ compared to over 51 years old $(n=28)(M=3.1429)$ with $p$-value .064 . Post Hoc test on RE and EE shows no difference based on age. $\mathrm{H}_{2}$ test results prove that dual process on the rational system or RA, and experiential system or EA, shows a difference based on age.

Table 7: ANOVA Findings for Dual Process vs Age

\begin{tabular}{lllllllll}
\hline & \multicolumn{3}{c}{ Sum } & of & Mean & & & Levene \\
Squares & & Df & Square & F & Sig. & Statistic & Sig. \\
\hline RA & Between groups & 4.008 & 4 & 1.007 & 2.171 & $.073^{*}$ & 3.142 & .015 \\
& Within groups & 106.157 & 230 & .462 & & & & \\
& Total & 110.166 & 234 & & & & & \\
RE & Between groups & 1.608 & 4 & .402 & 1.433 & .224 & .801 & .526 \\
& Within groups & 64.534 & 230 & .281 & & & & \\
& Total & 66.142 & 234 & & & & & .378 \\
EA & Between groups & 2.986 & 4 & .747 & 2.223 & $.067^{*}$ & 1.059 & \\
& Within groups & 77.252 & 230 & .336 & & & & \\
& Total & 80.238 & 234 & & & & & \\
& Between groups & 1.072 & 4 & .268 & .610 & .656 & 1.439 & .222 \\
& Within groups & 101.143 & 230 & .440 & & & & \\
& Total & 102.215 & 234 & & & & &
\end{tabular}

sig. $^{* *} \mathrm{p}<0.05^{*} \mathrm{p}<0.1$

Table 8 shows Levene test results with p-value $>0.05$, hence data is deemed homogeneous. Dual process ANOVA test result by education describes Post Hoc test on RA in high school group ( $n=40)(M=3.4675)$ shows a difference compared to doctoral group $(\mathrm{n}=6)(\mathrm{M}=4.3167)$ with $\mathrm{p}$-value .076; RA in undergraduate group $(n=155)(M=3.5058)$ shows a difference compared to doctoral group $(n=6)(M=4.3167)$ with $p$-value .091; RA on others group $(n=40)(M=3.3750)$ shows a difference compared to doctoral group $(n=6)(M=4.3167)$ with p-value .070. As is the case with RE in high school group $(n=40)(M=3.1800)$ shows a difference compared to doctoral group $(n=6)(M=3.8833)$ with $p$-value .049 ; $R E$ on undergraduate group $(n=155)(M=3.2310)$ shows a difference compared to doctoral group $(n=6)(M=3.8833)$ with p-value .070 . Post Hoc test on EA and EE shows no difference based on education. $\mathrm{H}_{2}$ test result proves dual process on the rational system, which is RA and RE, shows a difference based on education, but none in the experiential system, which is EA and EE.

Table 8: ANOVA Findings for Dual Process vs Education

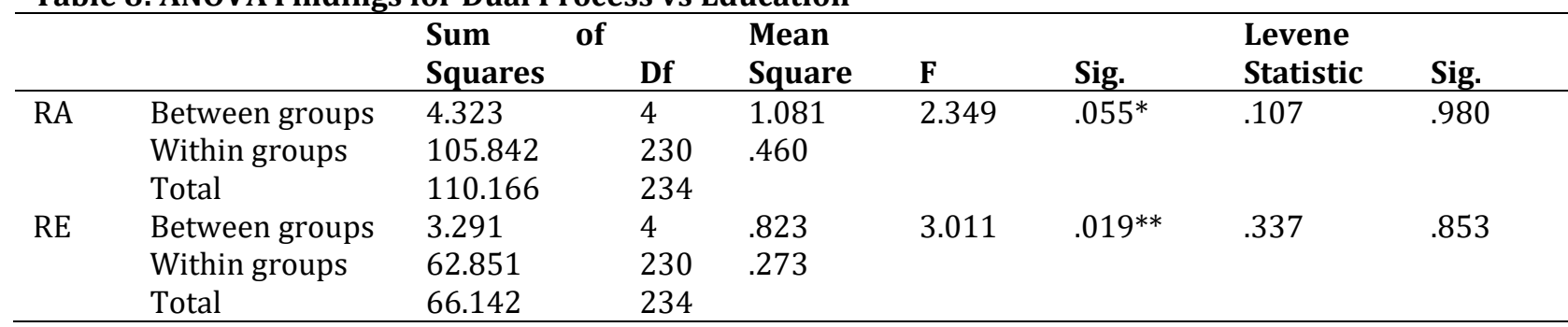




\begin{tabular}{|c|c|c|c|c|c|c|c|c|}
\hline \multicolumn{9}{|c|}{$\begin{array}{l}\text { Journal of Economics and Behavioral Studies (ISSN: 2220-6140) } \\
\text { Vol. 10, No. 6, pp. 272-284, December } 2018\end{array}$} \\
\hline \multirow[t]{3}{*}{ EA } & Between groups & .214 & 4 & .053 & .154 & .961 & .079 & .989 \\
\hline & Within groups & 80.024 & 230 & .348 & & & & \\
\hline & Total & 80.238 & 234 & & & & & \\
\hline \multirow[t]{3}{*}{$\mathrm{EE}$} & Between groups & 1.401 & 4 & .350 & .799 & .527 & .701 & .592 \\
\hline & Within groups & 100.815 & 230 & .438 & & & & \\
\hline & Total & 102.215 & 234 & & & & & \\
\hline
\end{tabular}

sig.** $\mathrm{p}<0.05 * \mathrm{p}<0.1$

Table 9 shows the Levene test with p-value $>0.05$, so data is deemed homogeneous. So, apart from RA, difference test among groups refers to Welch test. Dual process ANOVA test results based on FLC group describes Post Hoc test on EA in FLC Full Nest (M=3.0792) shows a difference compared to FLC Empty Nest $(\mathrm{M}=3.3857)$ with p-value .045 . RA, RE and EE show no difference based on $\mathrm{LFC}^{\mathrm{H}} \mathrm{H}_{3}$ test result proves dual process on the rational system, which is RA and RE, shows no difference compared to EE based on FLC, apart from an experiential system which is EA.

Table 9: ANOVA Findings for Dual Process vs Family Life Cycle

\begin{tabular}{|c|c|c|c|c|c|c|c|c|}
\hline & & $\begin{array}{ll}\text { Sum of } \\
\text { Squares }\end{array}$ & Df & $\begin{array}{l}\text { Mean } \\
\text { Square }\end{array}$ & $\mathbf{F}$ & Sig. & $\begin{array}{l}\text { Levene } \\
\text { Statistic }\end{array}$ & Sig. \\
\hline \multirow[t]{3}{*}{ RA } & Between groups & .949 & 2 & .475 & 1.008 & .366 & 3.466 & .033 \\
\hline & Within groups & 109.216 & 232 & .471 & & & & \\
\hline & Total & 110.166 & 234 & & & & & \\
\hline \multirow[t]{3}{*}{ RE } & Between groups & .725 & 2 & .363 & 1.286 & .278 & .658 & .519 \\
\hline & Within groups & 65.417 & 232 & .282 & & & & \\
\hline & Total & 66.142 & 234 & & & & & \\
\hline \multirow[t]{3}{*}{ EA } & Between groups & 2.368 & 2 & 1.184 & 3.528 & $.031^{* *}$ & 2.118 & .123 \\
\hline & Within groups & 77.870 & 232 & .336 & & & & \\
\hline & Total & 80.238 & 234 & & & & & \\
\hline \multirow[t]{3}{*}{$\mathrm{EE}$} & Between groups & 2.148 & 2 & 1.074 & 2.490 & $.085^{*}$ & 2.539 & .081 \\
\hline & Within groups & 100.067 & 232 & .431 & & & & \\
\hline & Total & 102.215 & 234 & & & & & \\
\hline
\end{tabular}

Discussion: Decision-making process of home buying is a complex process, involving both rational and experiential system. Rational system, which is Rational Ability (RA) and Rational Engagement (RE) and experiential system which is Experiential Ability (EA) and Experiential Engagement (EE). The result shows that each system does not show any significant difference toward buyers' dual motives. This is contradictory to the study of Njo, Made-Narsa, Irwanto (2017) which states buyers with consumption motive tend to have a rational decision compared to buyers with investment motive, which tend to be heuristic. The ability to think logically and analytically, with the pleasure of doing so, is hard to be distinguished in buyers with consumption motive. As is the case with the ability to recount impressions and intuitive feelings in one's self, with the feeling when deciding intuitively and based on feeling. It is hard to distinguish one from the other.

Buyers or investors profiles, if not grouped according to their demographical characteristic and structure, will make it hard to discern the cause and consequences of home buying decisions. Therefore, this study delves deep into the correlation of demographics in the dual system in buyers. Individual demography proves there is a difference based on gender, age, education, and family life cycle. Male tends to be more rational than female in both the ability to think and the pleasure in thinking logically. The age group of 41-50 years is superior to the 21-30 years group in the ability to analyze logically, while the 31-40 years group is superior to the over 51 years group in the ability to use both their experience and logic. The 31-50 years group shows personal maturity and logical thinking that is formed through their acquired knowledge and experience. Oppositely, those in the 21-30 years group are in the stage of forming their thinking logic, while those in the later stage are starting to lose theirs.

This study however, is contradictory to the study of Kokis et al. (2002) which states that the ability is a predictor to analytic reasoning, not caused by age. Dual system theory proves "controlled" cognitive process 
correlates with intelligence and individual working memory capacity, while "automatic" process does not correlate. The educational background shows a higher education leads to the domination of the rational system over experiential. Even more, this domination of the rational system is seen in every educational level. Shiloh \& Shenhav-Sheffer (2004) studied about "difficulties in the mate-selection decision", participants with higher rationality experienced less difficulty in making decisions regarding statements which measured difficulty in making decisions (e.g. doubt, unreliable information, and external conflict). On the contrary, participants with higher experiential style expressed they faced difficulties when asked to make an overall decision. This research also proved that each family depending on their own stages uses logic in thinking, so it is hard to distinguish their level of rationality. Rational system is an individual comprehension which is transmitted consciously, relatively slow and analytic.

Cognitively, every individual tends to use their logic, so it is hard to distinguish based on their life cycle. Conversely, the experiential system on later families (empty nest) is higher compared to younger families (full nest). Experiential system is a learning system that is presumptuous, quick, automatic, and holistic. The experiential system operates in contrast to the rational system; it works independently because of different rules, but remains interactive. Limited time and effort to gather information cause later families to process problem-solving and decision making rapidly. Experience is the best "teacher" to those families, which leads to a trade-off between loss of accuracy and the preservation of cognition and speed (Shah \& Oppenheimer, 2008). Heuristic behavior occurs in later families because they do not want the presence of heavy thinking and high complexity problems. The decisions made are biased and inefficient. Conclusions are drawn without effective consideration and analysis based on parameters used (Simon, 1978).

\section{Conclusion and Implications}

The rational and experiential system of buyers cannot be differentiated. But with deeper analysis on their characteristics based on demographic background, study shows there is a difference in the dual process based on gender, age, and education. There is also a difference based on family life cycle, especially on the experiential system regarding the ability to recount impressions and intuitive feelings of their own. On the other hand, the rational system on every family life cycle stage along with experiential system regarding feelings in making a decision using intuition cannot be differentiated. Dual process studies in decision making on buying a house is a tough process on every individual that although numerous considerations and logical thinking have been carried out. Psychological factors and experience will still affect the process. This dual process is so strongly imprinted that it is inevitable, but cognitive ability and time condition will play an active role as a guide to a rational or intuitive decision making. Therefore, a study on dual process still needs improvements to create an efficient real estate market. Understanding the behaviors of real estate buyers and investors can help create a stable market condition, thus reducing the volatility of property price.

\section{References}

Ajzen, I. (1991). The theory of planned behavior. Organizational behavior and human decision processes. 50, 179-211.

Anderson, B. A. (2015). World Population Dynamics: An Introduction to Demography. New Jersey: Person Education, Inc.

Bargh, J. A. (2002). Losing consciousness: Automatic influences on consumer judgment, behavior and motivation. Journal of Consumer Research, 29, 280-285.

Calder, L. A., Forster, A. J., Stiell, I. G., Carr, L. K., Brehaut, J. C., Perry, J. J. \& Croskerry, P. (2012). Experiential and rational decision making: A survey to determine how emergency physicians make clinical decisions. Emergency Medicine Journal, 29(10), 811-816.

Colom, R., Rebollo, I., Palacios, A., Juan-Espinosa, M. \& Kyllonen, P. C. (2004). Working memory is (almost) perfectly predicted. Intelligence, 32, 277-296.

Daly, J., Gronow, S., Jenkins, D. \& Plimmer, F. (2003). Consumer behaviour in the valuation of residential property: A comparative study in the UK, Ireland and Australia. Property Management, 21(5), 295314.

De Neys, W. (2006). Automatic-heuristic and executive-analytic processing during reason: chronometric and dual-task consideration. Q.J. Exp. Psychol, 1070-1100. doi:10.1080/02724980543000123 
DeLisle, J. R. (1985). Behavioral theory and residential appraisal. The Appraisal Journal, Oktober, 493-506.

Epstein, S. (1994). Integration of the cognitive and psychodynamic unconscious. American Psychologist, 49, 709-724.

Epstein, S. (1998). Constructive thinking: The key to emotional intelligence. Westport CT: Praeger Publishers.

Epstein, S. (2003). Cognitive-experiential self-theory of personality. In T. Hoboken, \& M. Lerner, Handbook of Psychology: Personality and Social Psychology (pp. 159-184). NJ: John Wiley \& Son Inc.

Epstein, S., Pacini, R., Denes-Raj, V. \& Heier, H. (1996). Individual differences in intuitive-experiential and analytical-rational thinking styles. Journal of Personality and Social Psychology, 71, 390-405. doi:10.1037/0022-3514.71.2.390

Evans, J. S. (1989). Bias in Human Reasoning: Causes and Consequences. Brighton: Erlbaum.

Evans, J. S. \& Curtis-Holmes, J. (2005). Rapid responding increases belief bias: Evidence for the dual-process theory of reasoning. Thinking \& Reasoning, 382-389.

Evans, J. S. \& Stanovich, K. E. (2013). Dual-Process Theories of Higher Cognition: Advancing the Debate. Perspectives on Psychological Science, 8(3), 223-241. doi:10.1177/1745691612460685

Gibler, K. M. \& Nelson, S. L. (2003). Consumer behavior applications to real estate education. Journal of Real Estate Practice and Education, 6(1), 63-89.

Gigerenzer, G. \& Gaissmaier, W. (2011). Heuristic decision making. Annual Review Psychology, 62, 451-482. doi:10.1146/annurev-psych-120709-145346

Gigerenzer, G. \& Goldstein, D. G. (1996). Rationing the fast and frugal way: models of bounded rationality. Psychol, 103, 650-669. doi:10.1037/0033- 295X.103.4.650

Gilinsky, A. S. \& Judd, B. B. (1994). Working memory and bias in reasoning across the life-span. Psychology and Aging, 9, 356-371.

Green, S. L. (May 2002). Rational choice theory: An overview. Baylor University Faculty Development Seminar on Rational Choice Theory.

Gunnell, J. J. \& Ceci, S. J. (2010). When emotionality trumps reason: a study of individual processing style and juror bias. Behavioral Science and the Law, 28(6), 850-877.

Han, H. \& Kim, Y. (2010). An investigation of green hotel customer's decision formation: Developing an extended model of the theory of planned behavior. International Journal of Hospitality Management, 29(4), 659-668.

Hardin, W. G. (1997). Heuristics use, credit constraints and real estate lending. Journal of Property Valuation and Investment, 15(1), 245-255.

Jensen, J., Calder, L., Walker, M., Travers, A., Tavares, W., Bienkowski, A. \& Croskerry, P. (2013). Experiential and rational clinical decision making: A survey to determine decision-making styles of paramedics. Canadian Journal of Emergency Medicine, 15(S1), 41.

Kahneman, D. (2003). Maps of bounded rationality: psychology for behavioral economics. American Economic Review, 93(5), 1449-1475.

Kahneman, D. \& Frederick, S. (2002). Representativeness revisited: Attribute substitution in intuitive judgement. In T.Gilovich, D. Griffin, \& D. K. (Eds.), Heuristics and biases: The psychology of intuitive judgement (pp. 49-81). Cambridge: Cambridge University Press.

Kahneman, D., Slovic, P. \& Tversky, A. (1982). Judgment Under Uncertainty: Heuristics and Biases. Cambridge, UK: Cambridge Univ. Press.

Kokis, J. V., MacPherson, R., Toplak, M. E., West, R. F. \& Stanovich, K. E. (2002). Heuristic and analytic processing: age trends and associations with cognitive ability and cognitive styles. J. Exp. Child Psychol, 83(1), 26-52.

Koklic, M. K. \& Vida, I. (2009). Koklic, M.K. \& Vida, I. (2009). A strategic household purchase: Consumer house buying behavior. Managing Global Transition, 7(1), 75-96. Managing Global Transition, 7(1), 75-96.

Kuester, S. (2012). In MKT 301: Strategic Marketing \& Marketing in Specific Industry Contexts (p. 110). University of Mannheim.

Kunshan, W. \& Yiman, T. (2011). Applying the extended theory of planned behavior to predict the intention of visiting a green hotel. African Journal of Business Management, 5(17), 7579-7587.

McAllister, P. \& Mansfield, J. R. (1998). Investment Property Portfolio Management and Financial Derivatives: Paper 1. Property Management, 16(3), 166-169.

Monico, M. (2013). Australian attitudes and behaviours towards buying their first home. Australian: RAMS First Home Buyers' Pulse Check Survey 2013. RAMS Financial Group Pty. Ltd. 
Newstead, S. E., Handley, S. J., Harley, C., Wright, H. \& Farelly, D. (2004). Individual differences in deductive reasoning. Quarterly Journal of Experimental Psychology, 57A, 33-60.

Nickerson, R. S. (1968). A note on long-term recognition memory for pictorial material. Psychonomic Science, 11(2), 58.

Njo, A., Made-Narsa, I. \& Irwanto, A. (2017). Dual process of consumption and investment motives in residential market Indonesia. Proceeding of 22nd International Conference on Advancement of Construction Management and Real Estate, CRIOCM 2017 (pp. 550-556). Melbourne: Springer.

Pacini, R. \& Epstein, S. (1999). The relation of rational and experiential information processing styles to personality, basic beliefs, and the ratio-bias phenomenon. Journal of Personality and Social Psychology, 76, 972-987. doi:10.1037/0022-3514.76.6.972

Peters, E., Diefenbach, M. A., Hess, T. M. \& Västfjäll, D. (2008). Age Differences in Dual Information-Processing Modes: Implications for Cancer Decision Making. Cancer, $113(12$ Suppl), 3556-3567. doi:10.1002/cncr.23944.

Reber, A. S. (1993). Implicit Learning and Tacit Knowledge. Oxford, UK: Oxford Univ. Press.

Scanlon, K. \& Whitehead, C. M. (2010). The economic rationality of landlords. Housing Economics Working Group (pp. 1-28). Copenhagen, Denmark: LSE Research Online. Retrieved from http://eprints.lse.ac.uk/29951/.

Shah, A. K. \& Oppenheimer, D. M. (2008). Heuristics made easy: An effort-reduction framework. Psychological Bulletin, 134(2), 207-222. doi:1.1037/0033-2909.134.2.207

Shiller, R. J. (2007). Understanding recent trends in house prices and home ownership. NBER (National Bureau of Economic Research, Inc), 1-46.

Shiloh, S. \& Shenhav-Sheffer, M. (2004). Structure of difficulties in mate-selection decisions and its relationship to rational and intuitive cognitive styles. Personality and Individual Differences, 37, 259273.

Shiloh, S., Salton, E. \& Sharabi, D. (2002). Individual differences in rational and intuitive thinking styles as predictors of heuristic responses and framing effects. Pers. Individ. Dif., 32, 415-429. doi:10.1016/S0191-8869(01) 00034-4

Simon, H. A. (1973). The structure of ill-structured problems. Artificial Intelligence, 4(3), 181-201.

Simon, H. A. (1978). Information processing theory of human problem-solving. In W. (. Estes, Handbook of Learning and Cognitive Processes (pp. 271-295). Erlbaum, Hillsdale, NJ.

Sladek, R. M., Bond, M. J., Huynh, L. T., Chew, D. P. \& Phillips, P. A. (2008). Thinking styles and doctors' knowledge and behaviours relating to acute coronary syndromes guidelines. Implementation Science, $3,23$.

Smith, A. (1992). The Redefining: Real Estate's Role in Fund Portfolios. Pension World, 28(11), 12-14.

Smith, E. R. \& DeCoster, J. (2000). Dual-process models in social and cognitive psychology: Conceptual integration and links to underlying memory systems. Personality and Social Psychology Review, 4, 108-131.

Spanier, G. B., Sauer, W. \& Larzelere, R. (1979). An Empirical Evaluation of the Family Life Cycle. Journal of Marriage and Family, 41(1), 27-38.

Stanovich, K. E. (1999). Who is Rational? Studies of Individual Differences in Reasoning. Mahway, NJ: Lawrence Erlbaum Associates.

Stanovich, K. E. \& West, R. F. (1998). Individual differences in framing and conjunction effect. Think. Reason, 4, 289-317. doi:10.1080/135467898394094

Tversky, A. \& Kahneman, D. (1973). Availability: A heuristic for judging frequency and probability. Cognitive Psychology, 5(2), 207-232.

Tversky, A. \& Kahneman, D. (1974). Judgment under uncertainty: heuristics and biases. Science, 185(4157), 1124-1131.

Acknowledgement: The authors gratefully acknowledge that the present research is supported by the Ministry of Research, Technology and Higher Education of the Republic of Indonesia under the "Penelitian Strategies Nasional 2018" (PSN) Research Grant Scheme (No: 002/SP2H/LT/K7/KM/2017). 


\section{Appendix - Questionnaire REI 40}

\section{Rational Ability}

1. I have a logical mind.

4. I am not a very analytical thinker.*

8. I don't reason well under pressure.*

13. I am much better at figuring things out logically than most people.

14. I usually have clear, explainable reasons for my decisions.

17. I have no problem thinking things through carefully.

25. I'm not that good at figuring out complicated problems.*

27. Reasoning things out carefully is not one of my strong points.*

30. Using logic usually works well for me in figuring out problems in my life.

39. I am not very good at solving problems that require careful logical analysis.*

\section{Rational Engagement}

2. I prefer complex problems to simple problems.

6. I try to avoid situations that require thinking in depth about something.*

10. Thinking hard and for a long time about something gives me little satisfaction.*

16. Thinking is not my idea of an enjoyable activity.*

20. Learning new ways to think would be very appealing to me.

26. I enjoy intellectual challenges.

28. I enjoy thinking in abstract terms.

32. I don't like to have to do a lot of thinking.*

33. Knowing the answer without having to understand the reasoning behind it is good enough for me.*

40. I enjoy solving problems that require hard thinking.

\section{Experiential Ability}

3. I believe in trusting my hunches.

5. I trust my initial feelings about people.

18. When it comes to trusting people, I can usually rely on my gut feelings.

19. I can usually feel when a person is right or wrong, even if I can't explain how I know.

21. I hardly ever go wrong when I listen to my deepest gut feelings to find an answer.

34. Using my gut feelings usually works well for me in figuring out problems in my life.

35. I don't have a very good sense of intuition.*

36. If I were to rely on my gut feelings, I would often make mistakes.*

37. I suspect my hunches are inaccurate as often as they are accurate.*

38. My snap judgments are probably not as good as most people's.*

\section{Experiential Engagement}

7. I like to rely on my intuitive impressions.

9. I don't like situations in which I have to rely on intuition.*

11. Intuition can be a very useful way to solve problems.

12. I would not want to depend on anyone who described himself or herself as intuitive.*

15. I don't think it is a good idea to rely on one's intuition for important decisions.*

22. I think it is foolish to make important decisions based on feelings.*

23. I tend to use my heart as a guide for my actions.

24. I often go by my instincts when deciding on a course of action.

29. I generally don't depend on my feelings to help me make decisions.*

31. I think there are times when one should rely on one's intuition. *reverse the score of statement 